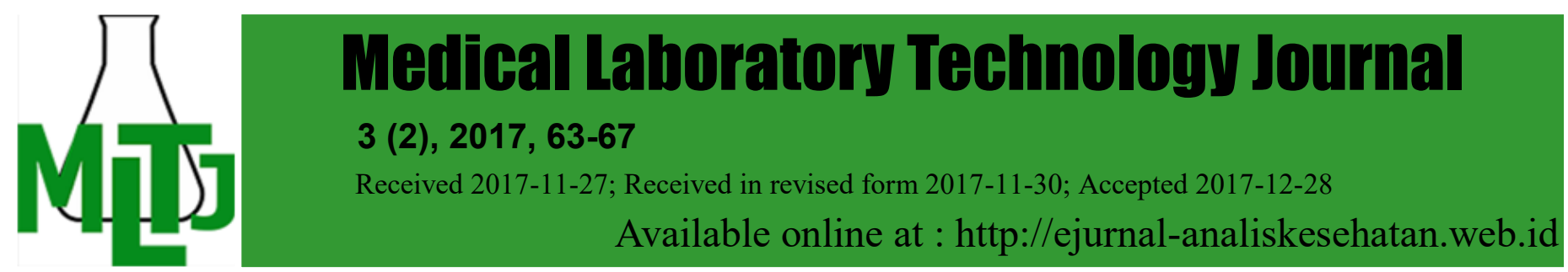

\title{
POTENSI ANTIFUNGI TANGKAI DAUN JARAK PAGAR TERHADAP PERTUMBUHAN Candida albicans
}

\author{
Ni Made Niagita Wiratni, I Nyoman Jirna, IGA. Sri Dhyanaputri \\ Jurusan Analis Kesehatan Poltekkes Kemenkes Denpasar \\ JI Sanitasi no 1Sidakarya, Denpasar Selatan, Bali \\ e-mail: nyomanjirna@ymail.com
}

\begin{abstract}
Jatropha curcas twigs are part of the Jatropha curcas which can be utilized as herbal treatment by the community to overcome the vaginal discharge problem. Vaginal discharge is a common symptom experienced by most women caused by Candida albicans infection. This research used the true experiment with posttest only control design which aimed to know the content of phytochemistry and antifungal potential of Jatropha curcas twigs extract on Candida albicans growth. Extract of Jatropha curcas in this study was obtained through a solvent extraction process using ethanol $96 \%$ by the method of maceration. The method used for the phytochemistry test was a qualitative method, while for the antifungal potential test was done by diffusion method with the concentration of $10 \%, 25 \%, 30 \%, 40 \%$ and $50 \%$. The results of Phytochemistry test showed that Jatropha curcas twigs extracts are saponins, tannins, and flavonoids, but no alkaloid compounds were found, however a test result of the antifungal potential test showed that the average diameter of inhibition zone of Candida albicans growth is 0 $\mathrm{mm}$. The conclusion of this study is Jatropha curcas twigs extracts can not inhibit Candida albicans growth, For other researchers which use jatropha curcas twigs, are suggested to do a phytochemical test quantitatively and to test the antifungal potential with dilution method.
\end{abstract}

Keywords: Jatropha curcas twigs, antifungal Candida albicans

Abstrak: Tangkai daun Jarak pagar merupakan bagian dari Jarak pagar yang bisa dimanfaatkan sebagai pengobatan herbal oleh masyarakat untuk mengatasi masalah keputihan. Keputihan adalah gejala yang umum dialami oleh sebagian besar wanita yang disebabkan oleh infeksi Candida albicans. Penelitian ini eksperimen murni dengan desain kontrol posttest yang bertujuan untuk mengetahui kandungan fitokimia dan potensi antijamur ekstrak tangkai daun jarak pagar terhadap pertumbuhan Candida albicans. Ekstrak tangkai daun jarak pagar dalam penelitian ini diperoleh melalui proses ekstraksi pelarut dengan menggunakan etanol $96 \%$ dengan metode maserasi. Metode yang digunakan untuk uji fitokimia adalah metode kualitatif, sedangkan untuk uji potensi antijamur dilakukan dengan metode difusi dengan konsentrasi 10\%, 25\%, 30\%, 40\% dan 50\%. Hasil uji fitokimia menunjukkan bahwa ekstrak tangkai daun jarak pagar mengandung saponin, tanin, dan flavonoid, namun tidak ditemukan senyawa alkaloid, namun hasil uji potensi antijamur menunjukkan bahwa diameter rata-rata zona inhibisi terhadap pertumbuhan Candida albicans adalah $0 \mathrm{~mm}$. Kesimpulan dari penelitian ini adalah ekstrak tangkai daun jarak pagar tidak dapat menghambat pertumbuhan Candida albicans. Peneliti selanjutnya disarankan untuk melakukan uji fitokimia secara kuantitatif dan untuk menguji potensi antijamur tangkai daun jarak pagar dengan metode pengenceran.

Kata kunci: tangkai daun jarak pagar, antijamur Candida albicans 


\section{PENDAHULUAN}

Masalah keputihan merupakan gejala yang sering dialami oleh sebagian besar kaum wanita. Keputihan berarti keluarnya cairan yang berlebihan dari alat kelamin wanita.Vagina memproduksi cairan untuk menjaga kelembapan, membersihkan dari dalam, dan menjaga keasaman vagina karena banyak mengandung bakteri menguntungkan. Selama keseimbangan bakteri yang menguntungkan itu bagus, infeksi pada organ reproduksi wanita dapat dicegah (Irianto, 2014).

Kejadian keputihan sering disebabkan oleh infeksi Candida albicans karena banyak perempuan yang tidak mengetahui cara membersihkan daerah vaginanya, penyebab lainnya adalah vaginitis bacterial dan trichomonas vaginalis. Infeksi akibat jamur Candida sering disebut dengan kandidiasis. Insiden kandidiasis genitalis pada akhir-akhir ini mengalami peningkatan.Meningkatnya frekuensi ini karena sarana-sarana diagnostik penyakit tersebut belum cukup memadai dan akibat pemakaian antibiotik spektrum luas dalam jangka waktu cukup lama dan penggunaan kortikosteroid yang meningkat akhir-akhir ini, juga pemakaian kontrasepsi oral dapat mempengaruhi frekuensi kandidiasis (Irianto, 2014).

Salah satu tumbuhan yang dapat dimanfaatkan sebagai tanaman obat herbal oleh masyarakat adalah jarak pagar. Tanaman jarak pagar dapat dimanfaatkan sebagai tanaman obat herbal oleh masyarakat. Batang, daun dan buah tanaman jarak pagar mengandung getah yang mengandung senyawa alkaloid. Senyawa alkaloid tersebut disebut jatrofin, yang berfungsi sebagai senyawa anti kanker. Selain jatrofin getah jarak juga mengandung tanin. Getah jarak pagar yang banyak mengandung tanin yaitu pada bagian batang dan tangkai daun sebesar $18 \%$, sedangkan biji jarak pagar mengandung 34-45\% minyak kurkas (curcas oil) dan senyawa protcin yang bersifat meracun (Santoso, 2010).

Berdasarkan uraian diatas penulis bertujuan ingin menganalisis kandungan zat antifungi dan potensi antifungi tangkai daun jarak pagar jamur Candida albicans dengan melihat daya hambatnya

\section{BAHAN DAN METODE}

Jenis penelitian adalah Trueexperimental (eksperimen murni), dengan desaign Posttest only-control design (Noor, 2011). Besar sampel yaitu 30 sampel, didapatkan dengan membuat lima perlakuan ekstrak tangkai daun jarak konsentrasi $10 \%$, $20 \%, 30 \%, 40 \%$ dan $50 \%$. Jumlah ulangan yang dilakukan pada penelitian sebanyak tiga kali untuk masing-masing konsentrasi dan dua kali replikasi, ditambah dengan kontrol positif (Ketokonazol $200 \mathrm{mg}$ ) dan negative (etanol 96\%) (Hanafiah, 2005).

Penelitian ini dilakukan di laboratorium farmasi Fakultas MIPA untuk analisis fitokimia dan laboratorium Mikrobiologi Fakultas Kedokteran Universitas Udayana untuk uji potensi antifungi. Pengumpulan data dilakukan oleh peneliti dengan metode pemeriksaan laboratorium, dengan prosedur kerja meliputi tahapan : persiapan alat dan media, pembuatan ekstrak memakai pelarut etanol $96 \%$ selama $3 \times 24$ jam dengan metode maserasi, analisis fitokimia secara kualitatif , pembuatan kosentrasi ekstrak, dan pemeriksaan potensi antifungi dengan difusi cakram disk. Diawali persiapan sampel berupa pembuatan ekstrak tangkai daun jarak pagar, pembuatan konsentrasi ekstrak tangkai jarak pagar dengan 10\%, 20\%, 30\%, 40\% dan $50 \%$, persiapan cakram kosong untuk direndam ke dalam masing-masing konsentrasi ekstrak tangkai daun jarak pagar

Data yang diperoleh dalam penelitian ini kemudian dikelompokkan dalam bentuk tabel dan narasi. Kemudian dilakukan analisis dengan uji Anova untuk mengetahui perbedaan daya hambat potensi antifungitangkai daun jarak pagar pada jamur Candida albican pada berbagai konsentrasi, pembuatan suspensi jamur Candida albicans dari biakan murni. Selanjutnyadilakukan tahap pemeriksaan sebagai berikut Swab kapas steril dicelupkan ke dalam suspensi jamur, terus digoreskan merata pada permukaan media Sabouraud Dextrose Agar sampai seluruh permukaan tertutup rapat, diamkan selama 5 sampai 15 menit, dilakukan penempelan kertas cakram yang jenuh pada permukaan media Sabouraud Dextrose Agar, inkubasi pada suhu $37{ }^{\circ} \mathrm{C}$ selama 2-3 hari. Dialanjutkan dengan pengkuran diameter zona hambat dengan jangka sorong dalam satuan $\mathrm{mm}$. 


\section{HASIL DAN PEMBAHASAN}

\section{Hasil Analisis Fitokimia}

Hasil uji fitokimia menunjukkan bahwa ekstrak tangkai daun jarak mengandung senyawa flavonoid, saponin, dan tanin serta tidak mengandung senyawa alkaloid.pada tangkai jarak pagar (tabel 1).

Tabel 1. Hasil Uji Fitokimia Tangkai Daun Jarak Pagar

\begin{tabular}{|c|c|c|c|c|}
\hline No & $\begin{array}{l}\text { Golongan } \\
\text { Senyawa }\end{array}$ & Reagen & Hasil & Ket \\
\hline 1 & Alkaloid & $\begin{array}{l}\text { Pereaksi Mayer } \\
\text { Pereaksi Wagner } \\
\text { Pereaksi Dragendorff }\end{array}$ & $\begin{array}{l}\text { Tidak terbentuk endapan putih } \\
\text { Terbentuk endapan coklat } \\
\text { Tidak terbentuk endapan jingga }\end{array}$ & - \\
\hline 2 & Flavonoid & $\begin{array}{l}\text { Asam okasalat } \\
\text { Asam borat } \\
\text { Eter }\end{array}$ & Flourensensi kuning & + \\
\hline 3 & Saponin & Akuades & Busa & + \\
\hline 4 & Tanin & $\mathrm{Pb}$ & Terbentuk endapan putih & + \\
\hline
\end{tabular}

Keterangan: $(+)=$ positif,$(-)=$ negatif

\section{Hasil Potensi Antifungi}

Hasil perlakuan ekstrak tangkai daun jarak pagar konsentrasi 10\%, 20\%, 30\%, 40\% dan $50 \%$ terhadap Candida albicans pada pemeriksaan replikasi pertama dan kedua dengan keseluruhan pengulangan menunjukkan tidak ada potensi daya hambat, dengan nilai rata-rata $0 \mathrm{~mm}$ (tabel 2 ).

Tabel 2. Hasil Pengukuran Diameter Daya Hambat Pertumbuhan Candida albicans pada Ekstrak Tangkai Daun Jarak Pagar

\begin{tabular}{ccccccccc}
\hline \multirow{2}{*}{ Replikasi } & Pengulangan & \multicolumn{7}{c}{ Diameter daya hambat $(\mathrm{mm})$} \\
\cline { 3 - 10 } & $10 \%$ & $20 \%$ & $30 \%$ & $40 \%$ & $50 \%$ & Kontrol $(-)$ & Kontrol $(+)$ \\
\hline \multirow{2}{*}{ I } & 1 & 0 & 0 & 0 & 0 & 0 & 0 & 27 \\
& 2 & 0 & 0 & 0 & 0 & 0 & 0 & 26 \\
& 3 & 0 & 0 & 0 & 0 & 0 & 0 & 25 \\
\hline \multirow{2}{*}{ II } & 1 & 0 & 0 & 0 & 0 & 0 & 0 & 25 \\
& 2 & 0 & 0 & 0 & 0 & 0 & 0 & 28 \\
& 3 & 0 & 0 & 0 & 0 & 0 & 0 & 26 \\
\hline Rerata & & 0 & 0 & 0 & 0 & 0 & 0 & 26.17 \\
\hline
\end{tabular}

\section{Hasil Analisis Data}

Analisis statistika perbedaan potensi daya hambat pertumbuhan Candida albicans terhadap berbagai konsentrasi ekstrak tidak dapat dianalisis karena tidak adanya nilai $p$ setelah dilakukan analisis data, sehingga uji beda tidak dapat ditentukan. Hal ini dikarenakan tidak adanya varian dari nilai diameter zona hambat, maka dilakukan analisis perbedaan antara kontrol positif dengan perlakuan kosentrasi ekstrak. Setelah dilakukan pengujian kolmogorov smirnovdiperoleh hasil nilai $p<\alpha(0,000<0,05)$, yang menandakan data berdistribusi tidak normal, kemudian dilanjutkan uji beda dengan Mann-Whitney diperoleh hasil nilai probabilitas $p(0,002)<\alpha$ $(0,05)$ yang menandakan bahwa ada perbedaan antara kontrol positif dengan perlakuan $10 \%, 20 \%, 30 \%, 40 \%$ dan $50 \%$ ekstrak tangkai daun jarak pagar.

\section{Uji Analisis Fitokimia}

Hasil uji fitokimia, yaitu positif (+) alkaloid, flavonoid, saponin , tannin dan negative (-) senyawa alkaloid Hasil ini sesuai dengan penelitian yang menunjukkan bahwa hasil uji kualitatif golongan senyawa yang terdapat dalam ekstrak etanol daun jarak pagar secara KLT menunjukkan positif mengandung flavonoid, saponin, dan tannin (Nuria.dkk, 2009). Pada uji flavonoid ekstrak tangkai jarak pagar, hasil positif ditandai dengan adanya flouresensi kuning. Hal ini bertolak belakang dengan penelitian, yang menunjukkan bahwa pada serbuk ataupun hasil ekstrak dari biji jarak pagar tidak terdeteksi senyawa flavonoid (Iswantini.dkk,2011).

Senyawa tanin juga diperoleh hasil positif yang ditandai dengan terbentuknya endapan putih serta diperoleh hasil positif juga pada saponin yang ditandai dengan terbentuknya busa yang stabil dengan tinggi busa $\pm 3 \mathrm{~cm}$. Hasil ini sesuai dengan penelitian yang menunjukkan bahwa ekstrak daun jarak pagar kaya akan saponin dan tanin, sedangkan senyawa metabolit sekunder lainnya seperti alkaloid, fenol, flavonoid, steroid dan triterpenoid dalam kadar yang lebih rendah (Hanifah, 2010).

Senyawa alkaloid tidak ditemukan pada ekstrak tangkai daun jarak pagar, positif senyawa alkaloid ditandai dengan adanya endapan putih pada pereaksi Meyer, adanya endapan coklat pada pereaksi Wagner, dan adanya endapan jingga oleh pereaksi Dragendroff. Alkaloid dikatakan positif apabila diantara ketiga pereaksi terdapat dua pereaksi yang positif.Hasil negatif alkaloid yang diperoleh pada ekstrak tangkai daun jarak pagar menandakan bahwa pada bagian tangkai jarak pagar tidak terkandung senyawa alkaloid.

Pada penelitian menyatakan bahwa sampel serbuk ataupun hasil ekstrak dari biji jarak pagar (kulit dan endosperm) banyak mengandung alkaloid, sedangkan bagian batang kandungan alkaloidnya lebih sedikit dibandingkan bagian bijinya (Iswantini.dkk, 2011). Hal ini mendasari bahwa kemungkinan pada bagian tangkai alkaloidnya tidak dapat 


\section{Uji potensi antifungi}

Berdasarkan hasil penelitian yang dilakukan diperoleh hasil potensi antifungi dengan konsentrasi $10 \%, 20 \%, 30 \%, 40 \%$ dan $50 \%$ dengan menggunakan metode difusi cakram pada replikasi pertama dan kedua dari keseluruhan pengulangan adalah $0 \mathrm{~mm}$. Hasil dari perlakuan menunjukkan ekstrak tangkai daun jarak pagar pada berbagai konsentrasiyang diujikan tersebut tidak dapat menghambat pertumbuhan Candida albicans secara in vitro. Hal ini bertolak belakang dengan penelitian oleh Agnita (2014), menunjukkan bahwa ekstrak daun jarak pagar dapat menghambat pertumbuhan Candida albicans yaitu dengan konsentrasi hambat minimum6\% dengan rata-rata diameter $1,03 \mathrm{~cm}$, sedangkan konsentrasi hambat minimal rebusan daun jarak pagar yaitu $10 \%$ dengan rata-rata diameter zona hambat $5,73 \mathrm{~cm}$. Penelitian lain dilaporkan olehSetyaningsih, Pandji, dan Perwatasari (2014), menunjukkan hasil pengujian ekstrak dan fraksi jarak pagar pada konsentrasi ekstrak $1 \%, 2 \%$ dan $3 \%$ tidak mampu menghambat pertumbuhan Candida albicans.

Salah satu faktor yang menyebabkan ketidakmampuan ekstrak tangkai jarak pagar menghambat pertumbuhan Candida albicans disebabkan oleh susunan struktur jamurnya yang kompleks.Jamur mempunyai jenis sel yang mirip dengan dengan sel mamalia dimana sama-sama masuk dalam kelompok eukariota, sehingga harus dicari antijamur yang dapat merusak jamur tetapi tidak merusak sel mamalia.Hal ini sulit dilakukan, berbeda dengan antibakteri, bakteri termasuk kelompok prokariota sehingga sel yang menjadi target antibakteri tidak dijumpai pada sel mamalia, sehingga perkembangan obat antibakteri lebih maju dibanding obat antijamur (Amelia, 2011). Mekanisme penghambatan pertumbuhan Candida albicans adalah dengan mengganggu atau merusak membran sel, menghambat biosintesis ergosterol dalam sel jamur dan menghambatan mitosis jamur (Rochani, 2009), maka dari itu diperlukan senyawa metabolit sekunder yang memiliki fungsi yang sama untuk menghambat pertumbuhan Candida albicans.

Hasil uji fitokimia, mengandung flavonoid, tanin dan saponin, namun senyawa tersebut belum dapat untuk menghambat pertumbuhan Candida albicans. Hal ini diduga karena jumlahdari kandungan senyawa me- tabolit sekunder yang telah disebutkan tidakkuat untuk menghambat pertumbuhan jamur tersebut. Skrining fitokimia yang dilakukan pada penelitian ini hanya dapat membuktikan adanyasuatu senyawa metabolit sekunder secara kualitatif, tidak secara kuantitatif. Selain itu, belum ada penelitian yang menyebutkan jumlah minimal suatu senyawa metabolit sekunder untuk menghambat Candida albicans, sehingga tidak dapat ditentukan berapakah jumlah senyawa metabolit sekunder yang didapat dari ekstrak tangkai jarak pagar yang cukup untuk menghambat pertumbuhan Candida albicans.

Adanya ergosterol yang merupakan lapisan sterol pada jamur berfungsi sebagai permeabilitas lapisan ganda serta mengatur sebagian besar sifat cair pada membran yang berperan penting sebagai sasaran antijamur (Amelia, 2011). Senyawa metabolit sekunder yang mempunyai kemampuan untuk berikatan kuat dengan ergosterol adalah alkaloid.Alkaloid dapat berikatan kuat dengan ergosterol sehingga membentuk lubang yang menyebabkan kebocoran membran sel sehingga ion $\mathrm{K}$, fosfat anorganik, asam karbosilat, asam amino dan ester fosfat keluar dari dalam sel jamur. Hal ini mengakibatkan kerusakan yang tetap pada sel dan kematian sel pada jamur. Namun, dalam penelitian ini senyawa alkaloid dalam uji fitokimia tidak ditemukan pada ekstrak tangkai daun jarak.Diduga hal ini yang menyebabkan tidak adanya daya hambat pertumbuhan Candida albicans terhadap ekstrak tangkai daun jarak pagar (Bhaskara, 2012).

\section{KESIMPULAN}

Analisis fitokimia pada ekstrak tangkai daun jarak pagar menunjukkan positif adanya senyawa metabolit sekunder berupa flavonoid, saponin dan tanin, namun senyawa alkaloid tidak terdeteksi. Diameter daya hambat ekstrak tangkai jarak pagar konsentrasi $10 \%$, $20 \%, 30 \%, 40 \%$ dan $50 \%$ terhadap pertumbuhan Candida albicans diperoleh hasil $0 \mathrm{~mm}$. Terdapaat perbedaan pertumbuhan jamur Candida albicans pada ekstrak tangkai daun jarak pagar dengan konsentrasi 10\%, 20\%, $30 \%, 40 \%$ dan $50 \%$ dengan kontrol positif setelah dilakukan uji statistika. 


\section{SARAN}

Bagi peneliti lain disarankan melakukan penelitian mengenai pengujian fitokimia secara kuantitatif untuk mengetahui persentase kandungan zat aktif yang terkandung dalam tangkai jarak pagar, serta perlu dilakukan pengujian daya hambat dengan metode yang dilusi. Penelitian terhadap tangkai jarak pagar ini dapat dilanjutkan dengan mengujikannya pada jenis jamur maupun jenis bakteri lain untuk menambah khasiat dari tangkai daun jarak pagar.

\section{DAFTAR PUSTAKA}

Agnita, P, J. W., \& Wahyuni, D. (2014). Perbedaan Daya Hambat Ekstrak Dan Rebusan Daun Jarak Pagar (Jatropha curcas linn) Terhadap Pertumbuhan Candida albicans. Retrieved from http:// repository.unej.ac.id/bitstream/ handle/123456789/73111/Parka nita.pdf;sequence $=1$

Amelia, S. (2011). Obat Anti Jamur (Fungal). Retrieved from http://repository.usu.ac.id/ bitstream/handle/123456789/30412/

Kemoterapi\%2520Anti\%25\% 6020Jamur.pdf? sequence $=1$ \&isAllowed $=y$

Bhaskara, G. Y. (2012). Uji Daya Antifungi Ekstrak Etanol DaunSalam (Syzygium polianthum [Wight] Walp.) terhadap Candida albicans ATCC 10231 secara invitro. Retrieved from http:// eprints.ums.ac.id/22008/11/11._naskah_p ublikasi.pdf

Hanafiah, K. . (2005). Rancangan Percobaan Aplikatif. Jakarta: PT Raja Grafindo Persada.

Hanifah, S. W. (2010). Aktivitas Anthelmintik Ekstrak Daun Jarak Pagar (Jatropa curcas L.) Terhadap Cacing Pita dan Ascaridia galli. Retrieved from http:// repository.ipb.ac.id/jspui/ bitstream/123456789/63384/1/

D10swh.pdf

Irianto, K. (2014). Bakteriologi Medis, Mikologi Medis dan Virologi Medis. Bandung: Alfabeta.

Iswantini, D., A. Riyadhi, U. Kesumawati, R. Rosman, D. Mangunwidjaja, \& M. Rahminiwati. (2011). Potensi Jarak Pagar (Jatropha Curcas) Sebagai Larvasida Hayati Pencegah Penyakit Demam Berdarah Dengue (Determination Of Po- tential Used Of Jatropha Curcas Oil As Biological Larvacidal For Preventing Dengue Haemorraghic Fever). Jurnal IImu Pertanian Indonesia, 16(1), 7-13.

Noor. (2011). Metodologi Penelitian. Jakarta: Kencana Group.

Nuria, M. C., A. Faizatun, \& Sumantri. (2009). Uji Aktivitas Antibakteri Ekstrak Etanol Daun Jarak Pagar (Jatropha Curcas L) Terhadap Bakteri Staphylococcus aureus ATCC 25923, Escherichia coli ATCC 25922, dan Salmonella typhi ATCC 1408. Mediagro, 5(2), 26-37.

Rochani, N. (2009). Uji Aktivitas Antijamur Ekstrak Daun Binahong (Anredera cordifolia (Tenore) Steen) terhadapCandida albicans Serta Skrining Fitokimianya. Retrieved from http:// eprints.ums.ac.id/5267/1/K100050305.pdf Santoso, B. . (2010). Deskripsi Botani Jarak Pagar. Lombok Barat: Arga Puji Press. 